EISSN: 2706 -7947 ISSN: 2077- 4613

DOI: $10.36632 / \mathrm{mejas} / 2021.11 .3 .54$

Journal homepage: www.curresweb.com

Pages: 672-681

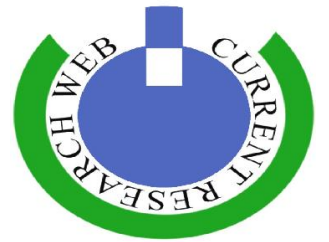

\title{
Effect of Turmeric powder on the Quality Attributes of Fish Sausage
}

\author{
Naglaa A. El-Senousi
}

Department of Meat and Fish Technology Research, Food Technology Research Institute, Agricultural Research Center, Giza, Egypt.

Received: 08 July 2021 Accepted: 20 August 2021 Published: 30 August 2021

\begin{abstract}
Fish products are a high-protein consumed food by a large percentage of the population due to its availability and palatability, and the fish industry has developed processed or minced fish products such as fish burgers, fingers and sausages. The aim of this study is to study the dual effect of turmeric utilization as an antimicrobial and an antioxidant. In addition its roles in improving the quality of fish sausage properties during frozen storage at $-18{ }^{\circ} \mathrm{C}$, which improving the shelf life and producing a healthy product. The obtained results indicated that in most estimates fish sausage samples contained $0.0,0.05,0.1$ and $0.2 \%$ turmeric powder showed no significant differences with respect to TBA values in zero time, while significant differences $(\mathrm{p}<0.05)$ were detected among the stored samples at $-18{ }^{\circ} \mathrm{C}$ for 30,60 and 90 days .There was, also found a significant increase in the number of milligrams malonaldehyde $/ \mathrm{kg}$ of sausage during 90 days of storage at $-18{ }^{\circ} \mathrm{C}$ in all samples, but the turmeric fish sausage samples contained fewer milligrams of malonaldehyde than the control sample: $(0.0 \%$ turmeric). The microbiological analysis (total number of bacteria, coliform bacteria, Staphylococcus aureus, yeasts and fungi) indicated a significant decrease in $\log _{10} \mathrm{cfu} / \mathrm{g}$ values with in storage period of 90 days at $-18^{\circ} \mathrm{C}$. The control sample $(0 \%$ turmeric powder) had the highest total bacterial count value of fish sausage samples after 30 days storage at $-18{ }^{\circ} \mathrm{C}$, while the total bacterial count values were gradually decreased as the turmeric powder concentration was increased during storage at $-18^{\circ} \mathrm{C}$ for 90 days. After 60 days of storage, the untreated samples (control: $0.0 \%$ turmeric powder) had the highest value ( $\log 10 \mathrm{cfu} / \mathrm{g}$ ) for Staphylococcus aureus compared to samples contained different concentrations of turmeric powder.The sensory properties of fish sausage indicated that all samples treated with turmeric powder had higher significant differences in taste and overall acceptability compared to untreated samples.
\end{abstract}

Keywords: Fish, sausage, turmeric powder, storage antimicrobial, antioxidant

\section{Introduction}

Fish is a highly proteins food consumed by a larger percentage of populace because of its availability and palatability. It is also known to be an excellent source of protein from amino acid composition and protein digestibility. Fish is also one of the main sources of protein in developing countries (Farid et al., 2016).

Turmeric is a spice derived from the rhizomes of Curcuma longa, which is a member of the ginger family (Zingiberaceae). Rhizomes are horizontal underground stems that send out shoots as well as roots. The bright yellow color of turmeric comes mainly from fat-soluble, polyphenolic pigments known as curcuminoids. Curcuma longa, the active ingredients present are turmeric oil and curcumin. It also contains curcuminoids altatone, bisdemethoxy curcumin, dimethoxy curcumin, diaryl heptanoids and tumerone (Phan et al., 2001), possess digestive and medicinal properties and is useful for humans (Govindarajan, 1980 and Ammon et al., 1992) having anti- inflammatory effects, antifungal (Wuthi udomler et al., 2000) and antibacterial activities (El Tantawy and Ayoub, 2016).

The use of antimicrobial substances is one of the most common methods to preserve and increase the durability of foods. Rising levels of health problems are linked to various food additives, with

Corresponding Author: Naglaa A. El-Senousi, Department of Meat and Fish Technology Research, Food Technology Research Institute, Agricultural Research Center, Giza, Egypt.

E-mail: elsenousi2006@gmail.com 
antimicrobial and preservative substances topping the list (Altunatmaz et al., 2016). Modern trends in the food market have introduced and increased ready-to-cook products that are easy to prepare and consume. In recent years, several studies have been carried out on antioxidant additives to increase the shelf-life of raw and cooked meat products (Moroney et al., 2012). Natural antioxidant additives could serve as an alternative to synthetic antioxidants (which are sometimes associated with toxic effects) due to their great acceptance by the consumers and for their demonstrated efficiency (Shah et al., 2014). Among natural antioxidants, is the Curcuma longa rhizome.

Turmeric extract $(0.5 \%)$ was applied to Sepia brevimana muscle to investigate its effects on muscle sensory evaluation, biochemical parameters, microbiological proliferation, and biogenic amine (BA) formation during storage at $4^{\circ} \mathrm{C}$ for 18 days.

Findings showed that turmeric extract is effective against lipid oxidation and could be a good strategy to enhance the shelf life of lamb sausag (de Carvalho et al., 2020).

The studies on the nutritional composition of turmeric and its antimicrobial properties; proximate, vitamin, mineral and phytochemical compositions of the turmeric were determined using standard methods. The results of the analysis shows that it contains $8.92 \%$ moisture content, $2.85 \%$ ash, 9.42 $\%$ crude protein, $4.60 \%$ crude fibre, and $6.85 \%$ fat. The methanolic extract of the plant exhibited significant inhibitory actions against Escherichia coli, Streptococcus, Staphylococcus, Bacillus cereus, Micrococcus, Pseudomonas, Aspergillus and Penicillium at a final concentration of $20 \mathrm{mg} / \mathrm{ml}$. The phytochemical results show that the plant contains $0.45 \%$ saponin, $1.08 \%$ tannin, $0.40 \%$ flavenoid, $0.08 \%$ phenol and $0.03 \%$ sterol (Ahamefula et al., 2014).

The essential oil has animicrobial activity against: Bacillus subtilis, Staphylococcus aureus and Pennicilium citrinum. (Pino et al., 2018).

The fish industry has been developing processed or minced fish products such as fish burgers, fingers and sausages, which add cooking convenience to nutritional benefits (Rahman et al., 2007). Fish flesh can be used as raw material for sausage production because muscle protein can form gel and act as an emulsifying agent. Fish sausage is a product in which fish flesh is mixed with additives, stuffed into suitable casings and heat processed. The sausage butter has decisive influence on quality factors of the finals products, such as texture, flavour, appearance and nutritive value. A sausage butter of constants composition also guarantees a predetermined uniformity of the final products throughout the production. This in turn, provides economic advantage to the processor and continued satisfaction to customer (Ahmed and Elhaj, 2011).

The addition of 3.5\% turmeric powder in rabbit burgers exerts an antioxidant effect during storage and it seems more effective in controlling lipid oxidation than ascorbic acid after cooking (Mancini et al., 2016).

Yun et al., (2013) evaluated the quality characteristics of chicken sausage prepared with turmeric (Curcuma longa L) powder. The results showed that sausage prepared with turmeric powder has antioxidant activity and stability of fat oxidation during storage.

Sensory evaluation determined the shelf life of S. brevimana muscle to be 12 days for the controls and 15 days for the turmeric-treated samples. The biochemical quality index differences were significant in all instances, and the values were improved in the turmeric-treated samples compared to the control samples. Most microbiological counts were higher in the control samples than in the turmeric-treated samples after 3 day. Additionally, the turmeric extract showed an inhibitory effect against some potential BA-forming bacteria. In conclusion, this study revealed the ability of turmeric extract to improve the shelf life and quality of $S$. brevimana muscle during chilled storage (Arulkumar et al., 2017).

The objective of this study was to investigate the dual effect of turmeric as an antimicrobial and antioxidant agent, to improve the quality of fish sausage properties during freezing storage at $-18^{\circ} \mathrm{C}$ and to enhance the shelf life and produce a healthy product.

\section{Materials and Methods}

\subsection{Materials}

Samples of fresh bolti fish fillet (Tilapia Nilotica) were brought from hyper market at Giza city. Sausage samples ingredients (salt, starch, black pepper, cubeba,onion, mutton tail fat and turmeric powder) were purchased from local markets in Giza, Egypt. 


\section{Fish minced preparation}

Fish samples were collected in polyethylene bags with crushed ice and transported to the processing laboratory. The fish samples were washed with cold water. The samples were minced using [ITalmans (Mod. TC32N) Prod.11/14 Tamb. $40^{\circ} \mathrm{C} 50 \mathrm{HZ2.2} \mathrm{KW.1430} \mathrm{remember} \mathrm{]} \mathrm{mincer.}$

\section{Formulation and preparation of bolti fish sausage samples}

The control sausage samples were prepared using the following ingredients: salt, starch, black pepper, cubeba, onion, mutton tail fat as listed in Table (1). The control sample is prepared without turmeric powder $(0.0 \%)$ to study the effect of adding the turmeric powder.To prepare the tested samples, the previous ingredients were used and the turmeric powder was added at different percentages $(0.05,0.1,0.2 \%)$. Formulation ingredients as described by (Fouda,1999).

Table 1: Formulation of bolti fish sausages.

\begin{tabular}{lc}
\hline Ingredients & Percentage \\
\hline Minced fish & 70.44 \\
Mutton tail fat & 7.96 \\
Salt (NaCl) & 2.09 \\
Starch & 6.80 \\
Black Pepper & 0.35 \\
Cubeba & 0.10 \\
Minced fresh onion & 0.26 \\
Garlic & 3.00 \\
Spices & 2.00 \\
Water (as ice flakes) & 7.00 \\
\hline
\end{tabular}

The minced meat was mixed with salt and fat, then let the scrambled mixture stand at $0^{\circ} \mathrm{C}$ for 2 hours. After the setting period, the mixture is then packed into a one-inch natural casing, by a sausage cannon, and finally the product is cooled and packaged in plastic bags and stored in the freezer at -18 ${ }^{\circ} \mathrm{C}$ for three months.

\subsection{Methods of analysis}

All analyzes are performed on raw fish sausage samples, except for sensory evaluation is performed on cooked fish sausage samples.

\subsubsection{Determination of thiobarbituric acid value (TBA)}

Thiobarbituric acid value was determined as described as Pearson (1970)

results were presented as $\mathrm{mg}$ of malonaldhyde / $\mathrm{kg}$ sample.

\subsubsection{Chemical analysis.}

Fish sausage samples were analyzed for moisture, protein, fat and ash according to AOAC (2000).

\subsubsection{Microbiological analysis.}

\section{Sample preparation}

Ten grams of representative fish sausage samples were taken and homogenized with $90 \mathrm{ml}$ of sterile physiological saline solution $(0.9 \% \mathrm{NaCl})$ in a blender, under sterile conditions, to give $1 / 10$ dilution. Serial dilutions were prepared to be used for counting total plate of bacteria, coliform bacteria, coagulase- positive staphylococci bacteria, yeast and mold counts.

\subsubsection{Total microbial count:}

The total plate of microbial count was determined using nutrient agar medium (APHA, 1976 and Difco Manual, 1984).

The ingredients were mixed and boiled to dissolve, dispensed into flasks and then autoclaved at $121^{\circ} \mathrm{C}$ for $15 \mathrm{~min}$. The melted medium was poured into inoculated petri dishes and plates were incubates after agar solidification at $32-35 \mathrm{oC}$ for $48 \mathrm{hr}$. All the colonies were counted representing the total microbial. 


\subsubsection{Coliform bacteria:}

The coliform bacteria were determined using Machonkey agar medium as a selective medium according to the method described by (APHA, 1976).

Machonkey agar medium Difco manual (1984) was used for counting coliform bacteria.The ingredients were mixed and boiled to dissolve them and then dispensed into flasks and autoclaved at $121{ }^{\circ} \mathrm{C}$ for $15 \mathrm{~min}$. The plates were incubated at $37{ }^{\circ} \mathrm{C}$ for $24-48 \mathrm{hr}$. Pink to red colonies with precipitation zone were recognized as coliform.

\subsubsection{Staphylococcus}

Staphylococcus aureus was determined using Baird Parker agar Base medium, as recommended by Baird Parker (1969). Baird Parker Base agar medium was selective for the isolation and enumeration of coagulase-positive staphylococci.

Medium components were suspended in cold distilled water, heated to boil, then distributed in flasks. Flasks containing medium were autoclaved at $121^{\circ} \mathrm{C}$ for $15 \mathrm{~min}$. After cooling the medium to $50{ }^{\circ} \mathrm{C}$, a volume of $50 \mathrm{ml}$ of egg yolk telluride emulsion was added to $1000 \mathrm{ml}$ of the medium. The mixture (medium + emulsion) was poured into inoculated petri dishes. After agar solidification, plates were incubated at $37{ }^{\circ} \mathrm{C}$ and the first reading was taken after $24 \mathrm{hr}$. The colonies of Staphylococcus aureus are black, shiny with a narrow white margin, surrounded by a zone of clearing of the medium. Incubation for further $24 \mathrm{hr}$, Staphylococcus aureus can give rise to colonies with a zone.

\subsubsection{Yeasts and moulds}

Yeasts and moulds were determined using Malt Agar medium as recommended by APHA (1976).

\subsubsection{Sensory evaluation}

Frozen fish sausages were thawed and cooked in boiling water for 10 minutes. The subjective evaluation of the product quality was carried out by ten sensory panelists from the Food Technology Research Institute staff. Quality attributes investigations included appearance, color, flavor, taste, texture and overall acceptability. Panel members scored all factors on a 10 point scale $(9-10=$ excellent; 8 - 8.9 = very good; 6.5-7.9 good; 5-6.4 fair; $<5$ bad), using the score method as reported by Ahmed and Elhaj (2011).

\subsection{Statistical analysis}

Data were analyzed using ANOVA and Duncan's test at a probability level of $(\mathrm{P}<0.05)$ according to SAS Institute (1987).

\section{Results \& Discussion}

The results of chemical composition of fish sausage samples treated with different percentages of turmeric powder $(\mathrm{g} / 100 \mathrm{~g})$ are shown in Table (2).

Table 2: Chemical composition of fish sausage samples treated with different percentages of turmeric powder $(\mathrm{g} / 100 \mathrm{~g})$

\begin{tabular}{lcccc}
\hline \multirow{2}{*}{ Parameters } & \multicolumn{4}{c}{ Treated sausage samples with turmeric powder } \\
\cline { 2 - 5 } & $\mathbf{0 \%}$ & $\mathbf{0 . 0 5 \%}$ & $\mathbf{0 . 1 \%}$ & $\mathbf{0 . 2 \%}$ \\
\hline Moisture\% & $69.23^{\mathrm{B}} \pm 0.1$ & $69.29^{\mathrm{B}} \pm 0.1$ & $69.33^{\mathrm{B}} \pm 0.1$ & $69.65^{\mathrm{A}} \pm 0.1$ \\
Protein\% & $12.46^{\mathrm{C}} \pm 0.06$ & $12.42^{\mathrm{C}} \pm 0.04$ & $13.38^{\mathrm{B}} \pm 0.08$ & $14.30^{\mathrm{A}} \pm 0.1$ \\
Ash\% & $2.60^{\mathrm{B}} \pm 0.05$ & $2.51^{\mathrm{C}^{\mathrm{A}} \pm 0.03}$ & $2.62^{\mathrm{B}} \pm 0.04$ & $2.74^{\mathrm{A}} \pm 0.04$ \\
Fat\% & $8.55^{\mathrm{B}} \pm 0.1$ & $8.45^{\mathrm{BC}^{\mathrm{C}} \pm 0.05}$ & $8.77^{\mathrm{A}} \pm 0.07$ & $8.31^{\mathrm{C}} \pm 0.1$ \\
\hline Van
\end{tabular}

Values are shown as mean \pm standard deviation of triplicate measurements. Different capital letters in the same row indicate significant differences among sausages samples $(\mathrm{p}<0.05)$.

It could be observed that no obvious differences were found between the moisture content of all fish sausage samples except the sausage sample treated with $0.2 \%$ curcuma powder which having the highest value of moisture. The obtained results showed that the fish sausage samples contained 69.23 to $69.65 \%$ moisture, however, Ahmed and Elhaj (2011) found that fish sausage contained moisture 
ranged from 70.0 to $72.73 \%$. In the same samples, the protein were ranged from 12.42 to $14.30 \%$, ash ranged from 2.51 to 2.74 and finally fat ranged from 8.31 to $8.77 \%$. Significant differences in protein, ash and fat may be due to the addition of turmeric.

Thiobarbituric acid index (TBA) as mg malonaldehyde $/ \mathrm{kg}$ in fish sausage samples contained different percentages of turmeric powder and stored during 3 months at $-18{ }^{\circ} \mathrm{C}$ are demonstrated in Table (3).

TBA is widely used to indicate the extent of secondary lipid oxidation in seafood (Arulkumar et al., 2017).Thiobarbituric acid (TBA) test, malonaldehyde (MDA) released, is, also, a helpful indicator of fish quality that is mainly used for evaluation of oil stability and monitoring of deterioration during fish storage (Latip et al., 2013). It could be observed that fish sausage samples treated with $0.0,0.05$, 0.1 and $0.2 \%$ turmeric powder had non-significant differences at zero time. During storage at $-18{ }^{\circ} \mathrm{C}$ (90 days) the samples of fish sausage treated with tumeric powder had lower TBA values compared to untreated samples (control). The TBA values decreased by increasing the concentration of the turmeric powder.The obtained results showed significant differences among all fish sausage samples treated with different proportions of turmeric powder.

Table 3: Thiobarbituric acid (TBA) $\mathrm{mg}$ malonaldehyde/kg in fish sausage samples treated with different percentages of turmeric powder during 3 months of frozen storage at $-18^{\circ} \mathrm{C}$

\begin{tabular}{ccccc}
\hline \multirow{3}{*}{ Storage days } & \multicolumn{4}{c}{ TBA(mg mad/kg sample) } \\
\cline { 2 - 5 } & \multicolumn{4}{c}{ Treated sausage samples with turmeric powder } \\
\cline { 2 - 5 } & $\mathbf{0 \%}$ & $\mathbf{0 . 0 5 \%}$ & $\mathbf{0 . 1 \%}$ & $\mathbf{0 . 2 \%}$ \\
\hline $\mathbf{0}$ & $0.46^{\mathrm{A}} \mathrm{d}_{\mathrm{d}} \pm 0.01$ & $0.45^{\mathrm{AB}}{ }_{\mathrm{d}} \pm 0.01$ & $0.44^{\mathrm{AB}}{ }_{\mathrm{d}} \pm 0.01$ & $0.43^{\mathrm{B}}{ }_{\mathrm{d}} \pm 0.01$ \\
$\mathbf{3 0}$ & $0.91^{\mathrm{A}} \pm 0.01$ & $0.71^{\mathrm{B}}{ }_{\mathrm{c}} \pm 0.01$ & $0.67{ }^{\mathrm{C}} \pm 0.01$ & $0.61^{\mathrm{D}}{ }_{\mathrm{c}} \pm 0.01$ \\
$\mathbf{6 0}$ & $3.55^{\mathrm{A}} \pm 0.15$ & $3.24^{\mathrm{B}} \pm 0.04$ & $2.50^{\mathrm{C}}{ }_{\mathrm{a}} \pm 0.03$ & $2.27^{\mathrm{D}} \pm 0.07$ \\
$\mathbf{9 0}$ & $4.0^{\mathrm{A}}{ }_{\mathrm{a}} \pm 0.20$ & $2.95^{\mathrm{B}}{ }_{\mathrm{b}} \pm 0.20$ & $2.15^{\mathrm{C}}{ }_{\mathrm{b}} \pm 0.15$ & $2.13^{\mathrm{C}} \mathrm{C}_{\mathrm{b}} \pm 0.13$ \\
\hline
\end{tabular}

Values are shown as mean \pm standard deviation of triplicate measurements. Different capital letters in the same row indicate significant differences among samples $(\mathrm{p}<0.05)$ at the same storage day. Different small letters in the same column indicate significant differences among stored samples $(\mathrm{p}<0.05)$ at the same turmeric amount.

The results, also, indicated that the TBA values of the control $(0.0 \%$ turmeric powder) and the treated samples gradually decreased from 0.91 to $0.61 \mathrm{mg}$ malonaldehyde $/ \mathrm{kg}$ for fish sausage samples in control and $0.2 \%$, respectively, after 30 days and from 3.55 to $2.27 \mathrm{mg}$ malonaldehyde $/ \mathrm{kg}$, respectively, for fish sausage samples after 60 days. At the end of the storage period (90 days) at - 18 ${ }^{\circ} \mathrm{C}$ TBA showed significant differences among all fish sausage samples treated with different proportions of turmeric powder except for the fish sausage samples treated with 0.1 and $0.2 \%$ turmeric powder that showed no significant difference between them. The storage period, also, had an effect on the concentration of TBA, there was a significant increase in the number of milligrams of malonaldehyde $/ \mathrm{kg}$ fish sausage samples during 90 days storage at $-18^{\circ} \mathrm{C}$ for all samples. The concentration of TBA for untreated fish sausage samples after 90 days storage at $-18^{\circ} \mathrm{C}$ was $4 \mathrm{mg}$ malonaldehyde $/ \mathrm{kg}$ fish sausage samples, while the samples treated with turmeric powder gave values of $(2.95,2.15$ and 2.13 of mg malonaldehyde $/ \mathrm{kg}$ fish sausage samples when treated with $0.05,0.1$ and $0.2 \%$ turmeric powder) respectively.

Therefore, the best treatment to reduce TBA values in fish sausage samples stored at $-18^{\circ} \mathrm{C}$ for 90 days could be the samples treated with $0.2 \%$ turmeric powder in accordance with those reported by Arulkumar et al., (2017).

The TBA values for all samples at the end of the freezing storage period were within the permissible limits according to the Egyptian Standard ( ES,2005), whereas, the TBA value allowed is $4.5 \mathrm{mg}$ malonaldehyde $/ \mathrm{kg}$.

The total bacterial count $\left(\log _{10} \mathrm{cfu} / \mathrm{g}\right)$ of fish sausage samples treated with different percentages of turmeric powder during storage for 3 months at $-18^{\circ} \mathrm{C}$ are presented in Table (4). 
Table 4: Total bacterial count $\left(\log _{10} \mathrm{cfu} / \mathrm{g}\right)$ in fish sausage samples treated with different percentages of turmeric powder during 3 months of frozen storage at $-18^{\circ} \mathrm{C}$

\begin{tabular}{|c|c|c|c|c|}
\hline \multirow{3}{*}{ Storage days } & \multicolumn{4}{|c|}{ Total Bacterial Count } \\
\hline & \multicolumn{4}{|c|}{ Treated sausage samples with turmeric powder } \\
\hline & $\mathbf{0 \%}$ & $0.05 \%$ & $0.1 \%$ & $0.2 \%$ \\
\hline $\mathbf{0}$ & $5.602^{\mathrm{A}}{ }_{\mathrm{a}} \pm 0.010$ & $5.59^{\mathrm{A}}{ }_{\mathrm{a}} \pm 0.005$ & $5.599^{\mathrm{A}}{ }_{\mathrm{a}} \pm 0.005$ & $5.596^{\mathrm{A}}{ }_{\mathrm{a}} \pm 0.001$ \\
\hline 30 & $4.778^{\mathrm{A}} \mathrm{b} \pm 0.008$ & $3.74_{b}^{\mathrm{B}} \pm 0.008$ & $3.602^{\mathrm{C}} \mathrm{b} \pm 0.010$ & $3.00^{\mathrm{D}_{\mathrm{b}}} \pm 0.022$ \\
\hline 60 & $3.431_{c}^{\mathrm{A}} \pm 0.016$ & $3.00_{c}^{\mathrm{B}} \pm 0.348$ & $2.698^{\mathrm{B}}{ }_{\mathrm{c}} \pm 0.195$ & $2.477_{\mathrm{c}}^{\mathrm{B}} \pm 0.399$ \\
\hline 90 & $2.903^{\mathrm{A}} \pm 0.054$ & $2.332^{\mathrm{B}}{ }_{\mathrm{c}} \pm 0.021$ & $1.845^{\mathrm{C}} \mathrm{d}_{\mathrm{d}} \pm 0.012$ & $1.698^{\mathrm{D}} \mathrm{c} \pm 0.008$ \\
\hline
\end{tabular}

Values are shown as mean \pm standard deviation of triplicate measurements. Different capital letters in the same row indicate significant differences among samples $(\mathrm{p}<0.05)$ at the same storage day. Different small letters in the same column indicate significant differences among stored samples $(\mathrm{p}<0.05)$ at the same turmeric amount.

It could be observed that fish sausage samples treated with $0.0,0.05,0.1$ and $0.2 \%$ turmeric powder showed non-significant differences at zero time. The results showed that a significant decrease in the total bacterial count occurred with increased period of storage for 90 days at $-18^{\circ} \mathrm{C}$ and with increase concentration of turmeric powder. It could be, also, noticed that the values of total bacterial count of the control $(0.0 \%$ turmeric powder) and treated samples $(0.2 \%)$ gradually decreased from 4.778 to $3.00 \log _{10} \mathrm{cfu} / \mathrm{g}$ fish sausage samples, respectively, after 30 days and from 3.431 to $2.477 \log _{10} \mathrm{cfu} / \mathrm{g}$ fish sausage samples, respectively, after 60 days. At the end of the storage period the results revealed that significant decreased values of total bacterial count occurred with increased concentrations of turmeric powder from 2.903 (control) to $1.698 \log _{10} \mathrm{cfu} / \mathrm{g}(0.2 \%)$ fish sausage samples.

It could be indicated that the total bacterial count of untreated samples (control:0.0\% turmeric powder) had the highest value $\left(5.602 \log _{10} \mathrm{cfu} / \mathrm{g}\right)$ in fish sausage samples at zero time while the lowest value was $1.698 \log _{10} \mathrm{cfu} / \mathrm{g}$ for the samples treated with $0.2 \%$ turmeric powder (after 90 days of storage).

The above results are consistent with those reported by Ahmed and Elhaj (2011) and also, Hayati et al., (2013) revealing the antibacterial effects of curcumin, also, the results of the total count of bacteria at the end of the freezing storage period were within the permissible limits according to the Egyptian Standard ( ES,2005), whereas, the maximum allowable total count of aerobic bacteria is one million cells/g.

Coliform bacteria $\left(\log _{10} \mathrm{cfu} / \mathrm{g}\right)$ of fish sausage samples contaied different percentages of turmeric powder during storage for 3 months at $-18^{\circ} \mathrm{C}$ are explained in Table (5).

Table 5: Coliform bacteria in fish sausage samples during storage time (cfu/g) treated with different percentages of turmeric powder during 3 months of frozen storage at $-18{ }^{\circ} \mathrm{C}$

\begin{tabular}{ccccc}
\hline \multirow{2}{*}{ Storagedays } & \multicolumn{5}{c}{ Coliform bacteria } \\
\cline { 2 - 5 } & \multicolumn{5}{c}{ Treated sausage samples with turmeric powder } \\
\cline { 2 - 5 } & $\mathbf{0 \%}$ & $\mathbf{0 . 0 5 \%}$ & $\mathbf{0 . 1 \%}$ & $\mathbf{0 . 2 \%}$ \\
\hline $\mathbf{0}$ & $-\mathrm{ve}$ & $-\mathrm{ve}$ & $-\mathrm{ve}$ & $-\mathrm{ve}$ \\
$\mathbf{3 0}$ & $-\mathrm{ve}$ & $-\mathrm{ve}$ & $-\mathrm{ve}$ & $-\mathrm{ve}$ \\
$\mathbf{6 0}$ & $-\mathrm{ve}$ & $-\mathrm{ve}$ & $-\mathrm{ve}$ & $-\mathrm{ve}$ \\
$\mathbf{9 0}$ & $-\mathrm{ve}$ & $-\mathrm{ve}$ & $-\mathrm{ve}$ & $-\mathrm{ve}$ \\
\hline & $-\mathrm{ve}$ & $-\mathrm{ve}$ & $-\mathrm{ve}$ & $-\mathrm{ve}$ \\
\hline
\end{tabular}

$-\mathrm{ve}=$ Not detected

No coliform bacteria were detected in all fish sausage samples.It is well known that coliforms are natural inhabitants of man alimentary tract and other mammals and therefore, their presence in relatively large numbers in fish may be due to contamination of such fish with polluted water (Frazier, 1988).

The coliform bacteria, and more specifically E.coli, has been used as an indicator of microbiological water quality (Partha, 2014).

Staphylococcus aureus $\left(\log _{10} \mathrm{cfu} / \mathrm{g}\right)$ in fish sausage samples treated with different percentages of turmeric powder during storage for 3 months at $-18^{\circ} \mathrm{C}$ are demonstrated in Table (6). 
Staphylococcus aureus is considered a pathogenic bacteria because it causes Staphylococcus food poisoning .It is a ubiquitous, versatile and highly adaptive pathogen that colonizes the skin and mucous membrane of the anterior nares, gastro-intestinal tracts, perineum, the genitourinary tracts and pharynx (Den Heijer et al., 2013). It is the causative agent of a wide range of infections in humans and animals with a significant impact on public health (Luzzago et al., 2014).

It could be observed that fish sausage samples treated with $0.0,0.05,0.1$ and $0.2 \%$ turmeric powder had non-significant differences for Staphylococcus aureus $\left(\log _{10} \mathrm{cfu} / \mathrm{g}\right)$ at zero time. The results showed that a significant $(\mathrm{p}<0.05)$ gradual decrease of values for Staphylococcus aureus $\left(\log _{10} \mathrm{cfu} / \mathrm{g}\right)$ for all fish sausage samples with increased period of storage for 90 days at $-18^{\circ} \mathrm{C}$, except for the concentration of $0.05 \%$ turmeric powder which showed non-significant decrease from 30 to 90 days of storage.

Table 6: Staphylococcus aureus $\left(\log _{10} \mathrm{cfu} / \mathrm{g}\right)$ in fish sausage samples treated with different percentages of turmeric powder during 3 months of frozen storage at $-18{ }^{\circ} \mathrm{C}$

\begin{tabular}{|c|c|c|c|c|}
\hline \multirow{3}{*}{ Storage days } & \multicolumn{4}{|c|}{ Staphylococcus aureus } \\
\hline & \multicolumn{4}{|c|}{ Treated sausage samples with turmeric powder } \\
\hline & $\mathbf{0 \%}$ & $0.05 \%$ & $0.1 \%$ & $0.2 \%$ \\
\hline $\mathbf{0}$ & $3.30^{\mathrm{A}} \pm 0.10$ & $3.25^{\mathrm{A}} \pm 0.10$ & $3.20^{\mathrm{A}} \pm 0.10$ & $3.12^{\mathrm{A}} \pm 0.12$ \\
\hline 30 & $3.00^{\mathrm{A}} \pm 0.10$ & $2.39^{\mathrm{B}}{ }_{\mathrm{b}} \pm 0.19$ & $2.30^{\mathrm{B}}{ }_{\mathrm{b}} \pm 0.10$ & $2.10^{\mathrm{B}} \pm 0.10$ \\
\hline 60 & $2.80^{\mathrm{A}} \pm 0.10$ & $2.25^{\mathrm{B}}{ }_{\mathrm{b}} \pm 0.12$ & $2.17^{\mathrm{B}}{ }_{\mathrm{b}} \pm 0.07$ & $1.84^{\mathrm{C}} \pm 0.11$ \\
\hline 90 & $2.40^{\mathrm{A}}{ }_{\mathrm{d}} \pm 0.10$ & $2.19^{\mathrm{B}}{ }_{\mathrm{b}} \pm 0.11$ & $2.00^{\mathrm{C}} \pm 0.08$ & $1.60^{\mathrm{D}} \pm 0.10$ \\
\hline
\end{tabular}

Values are shown as mean \pm standard deviation of triplicate measurements. Different capital letters in the same row indicate significant differences among samples $(\mathrm{p}<0.05)$ at the same storage day. Different small letters in the same column indicate significant differences among stored samples $(\mathrm{p}<0.05)$ at the same turmeric amount.

From Table (6), it could be detected decreased values $(\mathrm{p}<0.05)$ of Staphylococcus aureus $\left(\log _{10}\right.$ $\mathrm{cfu} / \mathrm{g}$ ) in fish sausage samples with increased concentrations of turmeric powder could be confirmed. After 30 days of storage at $-18^{\circ} \mathrm{C}$, the control sample $(0.0 \%$ turmeric powder $)$ had significant $(\mathrm{p}<0.05)$ higher value for Staphylococcus aureus compared to treated samples with different concentrations of turmeric powder (from 0.05 to $0.2 \%$ ) that showed no significant differences. After 60 days of storage at $-18{ }^{\circ} \mathrm{C}$ significant differences were observed among fish sausage samples treated with different concentrations of turmeric powder except the samples treated with 0.05 and $0.1 \%$ which had no significant differences between them. After 90 days of storage at $-18^{\circ} \mathrm{C}$ significant decreased values $(\mathrm{p}<0.05)$ for fish sausage samples were noticed from $2.40 \log _{10} \mathrm{cfu} / \mathrm{g}$ for thecontrol sample $(0.0 \%$ turmeric powder) to $2.19,2.00$ and $1.60 \log _{10} \mathrm{cfu} / \mathrm{g}$ for the concentrations of turmeric powder $(0.05,0.1$ and $0.2 \%$ ) respectively.

Therefore, the best treatment to reduce Staphylococcus aureus $\left(\log _{10} \mathrm{cfu} / \mathrm{g}\right)$ values of fish sausage samplesstored at $-18^{\circ} \mathrm{C}$ for 90 days could be the samples treated with $0.2 \%$ turmeric powder during 90 days storage, and is in the same line with those reported by Sandikci Altunatmaz, et al., (2016).

The values of Staphylococcus aureus obtained at the end of the freezing storage period were within the permissible limits according to the Egyptian Standard (ES, 2005), whereas, the maximum allowable limit for Staphylococcus aureus is 1000 cells/g.

Yeasts \& molds $\left(\log _{10} \mathrm{cfu} / \mathrm{g}\right)$ in fish sausage samples treated with different percentages turmeric powder during storage for 3 months at $-18^{\circ} \mathrm{C}$ are presented in Table (7).

Mould growth on foods stored at low temperatures is common and is a recurring problem. Certain molds are known to be capable of producing mycotoxins at low temperatures. Aflatoxin production is favored at temperature as low as $\left(-2\right.$ to $\left.10^{\circ} \mathrm{C}\right)$ but has been reported by temperature of 20 to $25^{\circ} \mathrm{C}$ (Hassan and Aziz, 1998).

From Table (7), it could be observed that fish sausage samples treated with $0.0,0.05,0.1$ and 0.2 $\%$ turmeric powder had non-significant differences for yeasts\&molds $\left(\log _{10} \mathrm{cfu} / \mathrm{g}\right)$ at zero time. The results showed that a significant $(\mathrm{p}<0.05)$ decrease was noticed in yeasts\&molds $\left(\log _{10} \mathrm{cfu} / \mathrm{g}\right)$ in all fish sausage samples with increasing the period of storage $\left(90\right.$ days at $\left.-18^{\circ} \mathrm{C}\right)$.

It could, also, be noticed that there was significant decreased values $(\mathrm{p}<0.05)$ of yeasts\&molds $\left(\log _{10} \mathrm{cfu} / \mathrm{g}\right)$ in fish sausage samples with increased concentrations of turmeric powder. Finally it could 
be concluded that a significant decrease $(\mathrm{p}<0.05)$ in yeasts \&molds $\left(\log _{10} \mathrm{cfu} / \mathrm{g}\right)$ for all fish sausage samples in all storage periods from zero time to 90 days at $-18^{\circ} \mathrm{C}$ and in all concentrations of turmeric powder compared to control.

Table 7: Yeasts \& molds $\left(\log _{10} \mathrm{cfu} / \mathrm{g}\right)$ in fish sausage samples treated with different percentages of turmeric powder during 3 months of frozen storage at $-18{ }^{\circ} \mathrm{C}$

\begin{tabular}{ccccc}
\hline \multirow{2}{*}{ Storage days } & \multicolumn{4}{c}{ Yeasts \& molds } \\
\cline { 2 - 5 } & \multicolumn{4}{c}{ Treated sausage samples with turmeric powder } \\
\cline { 2 - 5 } & $\mathbf{0 \%}$ & $\mathbf{0 . 0 5 \%}$ & $\mathbf{0 . 1 \%}$ & $\mathbf{0 . 2 \%}$ \\
\cline { 2 - 5 } & Mean \pm Sta. Dev. & Mean \pm Sta. Dev. & Mean \pm Sta. Dev. & Mean \pm Sta. Dev. \\
\hline $\mathbf{0}$ & $3.50^{\mathrm{A}}{ }_{\mathrm{a}} \pm 0.1$ & $3.48^{\mathrm{A}}{ }_{\mathrm{a}} \pm 0.1$ & $3.46^{\mathrm{A}} \mathrm{a}_{\mathrm{a}} \pm 0.16$ & $3.42^{\mathrm{A}}{ }_{\mathrm{a}} \pm 0.1$ \\
$\mathbf{3 0}$ & $3.30^{\mathrm{A}}{ }_{\mathrm{b}} \pm 0.1$ & $2.60^{\mathrm{B}}{ }_{\mathrm{b}} \pm 0.1$ & $2.23^{\mathrm{C}_{\mathrm{b}} \pm 0.1}$ & $0.0^{\mathrm{D}_{b} \pm 0.0}$ \\
$\mathbf{6 0}$ & $2.80^{\mathrm{A}}{ }_{\mathrm{c}} \pm 0.1$ & $1.92^{\mathrm{B}}{ }_{\mathrm{c}} \pm 0.12$ & $1.55^{\mathrm{C}}{ }_{\mathrm{c}} \pm 0.1$ & $0.0^{\mathrm{D}}{ }_{\mathrm{b}} \pm 0.0$ \\
$\mathbf{9 0}$ & $2.10^{\mathrm{A}}{ }_{\mathrm{d}} \pm 0.1$ & $1.30^{\mathrm{B}}{ }_{\mathrm{d} \pm 0.1}$ & $0.0^{\mathrm{C}}{ }_{\mathrm{d}} \pm 0.0$ & $0.0 \mathrm{C}_{\mathrm{b}} \pm 0.0$ \\
\hline
\end{tabular}

Values are shown as mean \pm standard deviation of triplicate measurements. Different capital letters in the same row indicate significant differences among samples $(\mathrm{p}<0.05)$ at the same storage day. Different small letters in the same column indicate significant differences among stored samples $(\mathrm{p}<0.05)$ at the same turmeric amount.

After 30 days storage at $-18^{\circ} \mathrm{C}$, there was a gradual decrease in yeasts \&molds $\left(\log _{10} \mathrm{cfu} / \mathrm{g}\right)$ values in fish sausage samples from 3.30 (control:0.0\%) to 2.60, 2.23 and $0.0 \log _{10} \mathrm{cfu} / \mathrm{g}$ for the concentrations of turmeric powder $\left(0.05,0.1\right.$ and $0.2 \%$, respectively), while after 60 days storage at $-18^{\circ} \mathrm{C}$, the control gave a value of 2.80 that decreased to $1.92,1.55$ and $0.0 \log _{10} \mathrm{cfu} / \mathrm{g}$ for the concentration of $0.05,0.1$ and $0.2 \%$ of turmeric powder, respectively. At the end of storage, after 90 days at $-18^{\circ} \mathrm{C}$, the control $(0.0 \%)$ was 2.10 which significantly decreased to $1.30,0.0$ and $0.0 \log _{10} \mathrm{cfu} / \mathrm{g}$ when treated with different concentrations of turmeric powder $(0.05,0.1$ and $0.2 \%)$ respectively.

The addition of turmeric powder was very effective as an antifungal agent especially the $0.2 \%$ concentration which gave a $0.00 \log _{10} \mathrm{cfu} / \mathrm{g}$ after 30 days of storage at $-18^{\circ} \mathrm{C}$ till the end of the experiment (90 days).

Our results are comparable with those of Arora and Kaur (1999) and Roth et al., (1998) who demonstrated the antifungal activity of turmeric extracts.

Sensory evaluation of cooked fish sausage samples treated with different percentages of turmeric powder during storage for 3 months at $-18^{\circ} \mathrm{C}$ are given in Table (8).

Table 8: Sensory evaluation of cooked fish sausage samples treated with different percentages of turmeric powder.

\begin{tabular}{lcccc}
\hline \multirow{2}{*}{ Parameters } & \multicolumn{4}{c}{ Treated sausage samples with turmeric powder } \\
\cline { 2 - 5 } & $\mathbf{0 \%}$ & $\mathbf{0 . 0 5 \%}$ & $\mathbf{0 . 1 \%}$ & $\mathbf{0 . 2 \%}$ \\
\hline Appearance & $9.0^{\mathrm{A}} \pm 0.86$ & $9.33^{\mathrm{A}} \pm 0.50$ & $9.0^{\mathrm{A}} \pm 0.86$ & $8.66^{\mathrm{A}} \pm 1.0$ \\
Color & $8.33^{\mathrm{B}} \pm 0.50$ & $9.16^{\mathrm{A}} \pm 0.25$ & $8.83^{\mathrm{AB}} \pm 0.66$ & $8.50^{\mathrm{B}} \pm 0.75$ \\
Flavor & $8.0^{\mathrm{B}} \pm 0.86$ & $8.5^{\mathrm{AB}} \pm 0.75$ & $9.16^{\mathrm{A}} \pm 0.25$ & $8.66^{\mathrm{AB}_{ \pm}} \pm 0.50$ \\
Taste & $7.3^{\mathrm{B}} \pm 0.50$ & $9.0^{\mathrm{A}} \pm 0.86$ & $9.0^{\mathrm{A}} \pm 0.86$ & $8.6^{\mathrm{A}} \pm 0.50$ \\
Texture & $8.0^{\mathrm{A}} \pm 0.86$ & $8.3^{\mathrm{A}} \pm 1.0$ & $8.5^{\mathrm{A}} \pm 1.1$ & $8.6^{\mathrm{A}} \pm 1.3$ \\
Overall acceptability & $7.50^{\mathrm{C}} \pm 0.75$ & $8.50^{\mathrm{B}} \pm 0.75$ & $8.50^{\mathrm{B}} \pm 0.75$ & $9.33^{\mathrm{A}} \pm 0.50$ \\
\hline
\end{tabular}

Values are shown as mean \pm standard deviation. Different capital letters in the same row indicate significant differences among sausages samples $(\mathrm{p}<0.05)$.

The organoleptic properties of the fish sausages indicated that the products were acceptable according to the panel's evaluation, in spite of, statistically, there were significant difference $(\mathrm{P}<0.05)$ in the sensory evaluation of different samples of the fish sausage. The obtained results of appearance and texture showed non-significant differences among all samples, while the results of flavor and taste indicated significant differences $(\mathrm{P}<0.05)$ with control sample $(0.0 \%$ turmeric powder $)$ and the treated samples with turmeric $(0.05,0.1$ and $0.2 \%)$ that had a higher acceptability than the control sample. As for the color, the best obtained results was for samples treated with turmeric $(0.05$ and $0.1 \%)$. Finally, 
all treated samples contained turmeric powder had higher significant differences $(\mathrm{P}<0.05)$ for overall acceptability than the turmeric free samples. The best overall acceptability was for fish sausage samples contained with $0.2 \%$ turmeric powder.

\section{Conclusions}

The results of the present study indicated a successful use of turmeric powder as an antimicrobial and antioxidant agent. In addition, it enhanced the shelf life and improved the overall acceptability of fish sausage stored at $-18^{\circ} \mathrm{C}$.

\section{References}

Ahamefula, I., G.I. Onwuka and N. Chibuzo, 2014. Nutritional Composition of Tumeric (Curcuma longa) and its Antimicrobial Properties. International Journal of Scientific \& Engineering Research, 5(10): 1085 - 1089.

Ahmed, E.O. and G.A. Elhaj, 2011. The chemical composition microbiological detection and sensory evaluation of fresh fish sausage made from clarias lazera and tetradon fahaka. Journal of Fisheries and Aquaculture, 2 (1):11-16.

Altunatmaz, S.S., F.Y. Aksu, G. Issa, B.B. Kahraman, D.D. Altiner, and S.K. Buyukunal, 2016. Antimicrobial effects of curcumin against L. monocytogenes, S. aureus, S. Typhimurium and E. coli O157:H7 pathogens in minced meat. Veterinarni Medicina, 61(5): 256-262.

Ammon, H.P., M.I. Anazodo, H. Safayhi, B.N. Dhawan and R.C. Srimal, 1992. Curcumin: a potent inhibitor of Leuotriene B4 formation in rat peritoneal polymorphonuclear neutrophils (PMNL). Planta Medica, 58(2):226.

AOAC, 2000. Official methods of analysis of Association of Official Analytical Chemists, $17^{\text {th }}$ Ed. Published by AOAC. IN. Gaithersburg, Maryland 20877- 2417. USA.

APHA, 1976. Standard method for the microbiological examination of dairy products. American Public Health Association. Broadway, New York, USA.

Arora, D.S. and J. Kaur, 1999. Antimicrobial activity of spices. Inter. J. Anti microb. Agents, 12: $257-$ 262. doi: 10.1016/S0924-8579(99)00074-6.

Arulkumar, A., K. Ramanchandran, S. Paramasivam, R. Palanivel and J.M. Miranda, 2017. Effects of turmeric (Curcuma longa) on shelf life extension and biogenic amine control of cuttlefish (Sepia brevimana) during chilled storage. CYTA - Journal of Food, 15(3):441-447.

https://doi.org/10.1080/19476337.2017.1296495.

Baird Parker, A.C., 1969. The use of Baird Paker's medium for the isolation and enumeratiuon of Staphylococcus aureus in foods "Isolation methods for microbiologists" Shapton, D.A. \& Goulded. London.

de Carvalho, F.A.L., P.E.S. Munekata, A.L. de Oliveira, M. Pateiro, R. Domínguez, M.A. Trindade and J.M. Lorenzo, , 2020. Turmeric (Curcuma longa L.) extract on oxidative stability, physicochemical and sensory properties of fresh lamb sausage with fat replacement by tiger nut (Cyperus esculentus L.) oil. Food Research International,136: 109487.

Den Heijer, C.D.J., E.M.E. Van Bijnen, W.J. Paget, M. Pringle, H. Goossens, C.A. Bruggeman, and E.E. Stobberingh, 2013. Prevalence and resistance of commensal Staphylococcus aureus, including meticillin-resistant $\mathrm{S}$ aureus, in nine European countries: a cross-sectional study. The Lancet Infectious Diseases, 13(5): 409-415. https://doi.org/10.1016/S1473- 3099(13)70036-7.

Difco manual, 1984. Dehydrated culture media and reagents for microbiological and clinical laboratory procedures, Pub. Difco-Lab. Detroit, Michigan, U.S.A.

El Tantawy, M.M. and H.F. Ayoub, 2016. Efficiency of oral Aeromonas hydrophila vaccine and Tumeric powder mixture on immune response of Nile tilapia (Oreochromis niloticus). Egy. J. Aquac., 6 (1):47-66. ISSN: 2090-7877.

ES.,2005. Egyptian Standards.No.889-2/2005. Frozen fish, part 2. Fish portions.

Farid, F.B., G.R. Latifa, S.C. Chakraborty, M.N. Nahid and M. Begum, 2016. Combine effect of Curcuma longa (turmeric) powder and dry-salt with sun-drying in quality changes of three freshwater fish species of Meghna River. European Journal of Biotechnology and Bioscience, 4 (10): 42-47. 
Frazier, W.C., 1988. Food Microbiology. 4th Ed. McGraw Hill Publ. Comp., Gamp., Bombay, New York : McGraw-Hill, (C1988. eBook: Document : English : 4th ed View all editions and formats. (not yet rated) with reviews - Be the first.

Fouda, Z.M.A.,1999. Quality attributes of fish sausage as affected by adding dietary fibers.Annal of Agric. Sci., Moshtohor, 37(2): 1287- 1298.

Govindarajan, V.S., 1980. Turmeric-chemistry, technology and quality. CRC Critical Reviews Food Science and Nutrition, 12(3):199-301.

Hassan, A.A. and N.H. Aziz, 1998. Influence of moisture content and storage temperature on the production of aflatoxin by Aspergillus flavus EA-8 1 in maize after exposure to gamma radiation. J. of Food Safety, 18(3): 159-17 1. (USA).

Hayati, G., G. Dumrul, M. Reyhan, G. Abdullah, T. Tekin, and E.T. Aynur, 2013. Antibacterial effects of curcumin: an in vitro minimum inhibitory concentration study. Toxicology and Industrial Health, 4: (1-5).

Latip, L.D., W. Zzaman, and T.A. Yang, 2013. Effect of chilled-frozen storage on the physico-chemical, microbial and sensory quality of farmed bighead carp (Hypophthalmichthys nobilis). J Fish Aquat Sci., $1-11$.

Luzzago, C., C. Locatelli, A. Franco, L. Scaccabarozzi, V. Gualdi, R. Viganò, G. Sironi, M. Besozzi, B. Castiglioni, P. Lanfranchi, and P. Cremonesi, 2014. Clonal diversity, virulence-associated genes and antimicrobial resistance profile of Staphylococcus aureus isolates from nasal cavities and soft tissue infections in wild ruminants in Italian Alps. Veterinary Microbiology, 170(1):157-61. https://doi. org/10.1016/j.vetmic.2014.01.016.

Rahman, M.S., H. Al-waili, N. Guizani and S. Kasapis, 2007. Instrumental-sensory evaluation of texture for fish sausage and its storage stability. J. Fisheries. Science, 73: 1166-1176

Moroney, N., M.N. O'Grady, J.V. O'Doherty and J.P. Kerry, 2012. Addition of seaweed (Laminaria digitata) extracts containing laminarin and fucoidan to porcine diets: Influence on the quality and shelf- life of fresh pork. Meat Sci., 92(4): 423-429.

Partha, P., 2014. Detection of coliforms in drinking water and its effect on human health - A Review. International Letters of Natural Sciences, 17: 122-131 Online: 2014-06-30 (C (2014) SciPress Ltd., Switzerland doi:10.18052/www.scipress.com/ILNS.17.122.

Pearson, D., 1970. The chemical analysis of food. 8th edition: Egan, Harold, Ronald S. Kirk, and Ronald National College of Food technology, Univ. of Reading Weybridges Surry, T. and A. Churchill.

Phan, T.T., P. See, S.T. Lee, and S.Y.Chan, 2001. Protective effects of Curcumin against oxidative damage on skin cells in vivo: Its implication for wound healing. Journal of Trauma, 51(5): 927931.

Pino, J.A., F.M. Fon-Fay, J.C. Pérez, A.S. Falco, I. Hernández, I. Rodeiro and M.D. Fernández, 2018. Chemical composition and biological activities of essential oil from turmeric (Curcuma longa L.) rhizomes grown in Amazonian Ecuador. Revista CENIC. Ciencias Químicas, 49(1) : 1-8.

Roth, G.N., A. Chandra, and M.G. Nair, 1998. Novel bioactivities of Curcuma longa constituents. J. Nat. Prod., 61(4):542-545. doi: 10.1021/np970459f.

Sandikci Altunatmaz, S., F. Yilmaz Aksu, and G. Issa, B2016. Antimicrobial effects of curcumin against L. monocytogenes, $S$. aureus, $S$. Typhimurium and E. coli $\mathrm{O} 157: \mathrm{H} 7$ pathogens in minced meat. Veterinarni Medicina, 61(5): 256-262

SAS Institute, 1987. SAS/STAT series Guide release 6.03 Ed., SAS institute Int., Cary MC, U.S.A.

Shah, M.A., S.J.D. Bosco, and S.A. Mir, 2014. Plant extracts as natural antioxidants in meat and meat products. Meat Sci., 98(1): 21- 33

Mancini, S., G. Preziuso, and G. Paci, 2016. Effect of turmeric powder (Curcuma Longa L) and Ascorbic acid on antioxidant capacity and oxidative status in Rabbit Burgers after cooking. June 2016World Rabbit Science, 24(2):121- 127

Wuthi-udomler, M., W. Grisanapan, O. Luanratana and W. Caichompoo, 2000. Antifungal activity of Curcuma longa grown in Thailand. Southeast Asian Journal of Tropical Medicine and Public Health, 31(1): 178-182.

Yun, E., E. Jung, and N. Joo, , 2013. Quality Characteristics of Chicken Sausage Prepared with Turmeric (Curcuma longa L.) during Cold Storage. Journal of the Korean Dietetic Association, 19 (3): 195-208. 